information-processing hypothesis, leads to the conclusion that a disease entity "schizophrenia" in the traditional sense does not exist, but only a quite unpredictable and to some extent always open lifeprocess in individuals with a particular kind of vulnerability. If valid, these new concepts have important theoretical and practical implications. Copies of the original manuscript are available on request.

Sozialpsychiatrische Universitätsklinik, Luc CiompI

Murtenstrasse 21,

CH-3010 Berne, Switzerland

\section{YOUNG INTELLECTUALLY RETARDED ADULTS}

DEAR SIR

It was with great interest that I read your report of Professor Brimblecombe's lecture on 'The Needs of Young Intellectually Retarded Adults' (Journal, January $1985,146,5-10$. In this context, it struck me that there could be one particular reason why such subjects often fail to integrate well in the community. Though the concept is a simple one, I cannot recall having ever seen it committed to print.

One reason for the non-acceptance of mentally retarded young persons, especially those with demonstrable brain-damage, ties in with the concept popularly designated as 'body-language'. The movements of such subjects tend to be jerky and their posture oddly wooden, while speech itself can often be slurred and/or abrupt. These traits are readily perceived as hostile and induce fear or counter-aggression.

Such a reaction by members of the general public is the more likely to persist, because this physical awkwardness of some retarded subjects is perceived intuitively rather than reasoned at a conscious level. It is this kind of reaction, for example, which causes mentally retarded young adults to be so often accused (usually unjustly) of threatened assault or sexual molestation.

Might it not be worth while, in any scheme that attempts to bring intellectually backward young adults into the community at large, to try and put over this point that 'normal' body-movements (which come readily, perhaps instinctively, to most of us) have often to be slowly and painfully learned by those who have the misfortune to be intellectually impaired?

The Old Manse, Rendall, Orkney, Scotland KW172EZ
ANOTHER BART'S ALUMNUS: W. H. R. RIVERS

DeAR SIR, I was somewhat disconcerted to note that Anthony Clare's historical review of psychiatry at St Bartholomew's Hospital (Journal, February 1985, 146, 120-126), makes no mention of W. H. R. Rivers, perhaps the most eminent of Bart's psychiatrists and surely the only one to become a Fellow of the Royal Society. Rivers trained and taught at Bart's and his first papers appeared in the Journal of that hospital (Slobodin, 1978).

Rivers was a polymath who strode across the disciplines of neurology, psychiatry, psychology and anthropology; to quote C. G. Seligman 'perhaps no man has ever approached the investigation of the human mind by so many routes' (Langham, 1981). His early work on physiological psychology including visual perception and the peripheral nervous systmen culminated in the famous studies with Henry Head on the regeneration of cutaneous nerves, a Fellowship at St John's, Cambridge, and the start of experimental psychology in Britain. Taking part in the Torres Straits expedition of 1898 , Rivers pioneered the first studies in cross-cultural psychology after which his interests turned to ethnology. His work on kinship and his rejection of the then current evolutionary hypotheses of cultural differences laid the foundation of the once dominant British School of structural-functionalism (Kuper, 1975).

Rivers returned to psychiatry during the First World War and as the director of the Maghull Hospital in Scotland was immortalised in the fiction of Robert Graves and Siegfried Sassoon, who both became close friends. He was an early champion of Freud in England and practised a pragmatic therapy of traumatic neurosis based on a watered-down version of psychoanalysis: in various books he synthesised psychodynamic and anthropological approaches to become the founder of cultural psychiatry. Rivers' wartime experiences led him, like so many others, to socialism; at the time of his death in 1922 he was the Labour parliamentary candidate for the University of London seat.

Queen Elizabeth Hospital.

ROLAND LitTLEWOOD

Birmingham B15 2TH

References

KUPER, A. (1975) Anthropologist and Anthropology: The British School 1922-1972, Harmondsworth: Penguin.

Langham, I. (1981) The Building of British Social Anthropology: W. H. R. Rivers and his Cambridge Disciples in the Development of Kinship Studies 1898-1931. Dordrecht: Reidel.

Slobodin, R. (1978) W. H. R. Rivers. New York: Columbia University Press. 